\title{
A BLUEPRINT OF RATIO ANALYSIS AS INFORMATION BASIS OF CORPORATION FINANCIAL MANAGEMENT
}

\author{
Maja Andrijasevic, Vesna Pasic \\ Megatrend University, Zajecar, Serbia \\ E-mail: maja.andrijasevic@fmz.edu.rs, vesna.pasic@fmz.edu.rs
}

\begin{abstract}
Ratio analysis, due to its simplicity, has, for a long time, been one of the most frequently used methods of financial analysis. However, the question is how its results are a good basis for assessment of financial condition of a company by the external users of financial reports. If one takes into account numerous limitations, one can rather say that ratio analysis is a rough approximation of financial situation. What are the limitations, can they be overcome and in what way, can they, at least, be reduced, and to what extent the user has to take a reserved attitude when making business decisions on the basis of ratio analysis? The last but not the least, we should accept the fact that by insisting on financial analysis other aspects of the analyses are, in practice frequently marginalized, thus neglecting the fact that actually they themselves in the most direct manner point to the causes of potential disorders in business activities of a company. Key words: financial management, ratio analysis, reliability.
\end{abstract}

\section{Introduction}

In complex economic conditions characterized by the process of internationalization and diversification of business activities, there is a rapid increase of factors of both external and internal nature that, by higher or lower intensity, affect business success of a company. To keep the success at the achieved level and to increase it to the desired level, it is necessary to identify these factors first and then to quantify them in some way.

For that purpose, we most frequently use analysis of business that, as continuation of the process of planning, has as its objective to determine the level of harmonization of the achieved results of business with the previously set objectives, determine cause of potential digressions and propose corrective measures for their elimination (Stavrić., 2010).

Analysis of business is a rather broad term including analysis of financial, tangible and intangible indicators of the scope and success of business activities, thus connecting all operations in a company and encompassing all available resources. Unlike it, financial analysis or analysis of balance, as it is frequently called, is only part of a complex analysis, but the part where analysis most frequently starts with and is considered very important since it presents business results in the form of numerical (and therefore easily understandable) indicators in that way simplifying the process of communication in an organization.

The number of methods and techniques of financial analysis is quite large, so that the applied technique in an organization primarily depends on the assessment of the company management referring to how useful it is and to what extent it 'fits' into their needs and requirements. In practice, ratio analysis is yet one of the most frequently used methods of financial analysis due to its simplicity.

According to the author, ratio analysis as a technique has its limitations that, in practice, are frequently neglected, which, to a great extent, reduce the validity of information provided 
PROBLEMS

OF MANAGEMENT

IN THE $21^{\text {st }}$ CENTURY Vol. 9, No. 2, 2014

118

in this way. Some of these limitations are possible too, at least, mitigate in a relatively simple manner and the author deals with this issue in the paper, in which she tries to overview the basic advantages and disadvantages of ratio analysis as a method and formulate the proposed measures that, in the author's opinion might be taken to increase the quality of information provided by ratio analysis.

\section{Use of Ratio Analysis}

Being one of the simplest techniques, ratio analysis is most frequently the first step in the analysis of financial condition and earning capacity of a company providing the basic information on the state of liquidity, solvency, the structure of assets and their resources, management efficiency and the degree of success. Ratio analysis is based on the study of different relations between logically connected balance sheet items including other relevant information. Basic purpose of ratio numbers is to enable evaluation of financial condition of a company, as well as, the trend of changes in the financial condition of a company. (Knezevic et al., 2001, p. 25)

Financial analysts use financial ratios to determine financial health of a company - its financial condition and its profitability (Malinic et al, 2012). These ratios are calculated to obtain comparisons that can be more useful than the 'raw' numbers themselves. However, when selecting positions in ratio and interpreting obtained ratio numbers one has to be careful and interpret each ratio in the light of industry standards since neglecting the nature of activity can lead to the wrong interpretation of ratio. (Zivi et al., 2009, p 437)

Analysis of financial ratios includes two types of comparisons. First, an analyst can consider one ratio in time, comparing the current ratio for that year with the current ratio for the previous year and in that way he can view forms of changes and define whether there is an improvement or deterioration of financial situation and success of a company over time.

The second type of comparison includes comparison of ratio for one company with the ratio for similar companies or with the industry average at the specific moment of time. Such a comparison provides information on any significant deviation from the applicable industry average. (James C.V.H., John M. W., 2007, p. 133) However, ratio of industry average should be used as guide not as a goal or target. Beside industry average for evaluation of company performances, ratios can be compared with benchmarks or a world-class competitor in the sector the company belongs to.

Most frequently, analytical procedure is divided into analysis of the balance sheet aimed at providing information on financial situation and analysis of income statement aimed at providing information on business efficiency of a company. In this context, one can distinguish two types of ratio: ratio of balance sheet summarizing aspect of financial condition of a company at the moment when balance sheet has been created and ratio of income statement summarizing the aspect of company efficiency usually within one year period. Furthermore, ratios can be divided into five large groups: ratio of liquidity, financial leverage (or indebtedness), coverage, activity and profitability (Table 1). To get the proper picture of financial condition and efficiency of a company a group must be analyzed. 
Table 1. Types of ratio.

\section{RATIO OF BALANCE SHEET}

I) Ratio of financial leverage (indebtedness) shows the extent to which a company can be financed by indebtedness.

1. Interest burden $\frac{E B I T-\cos t_{s} \_ \text {int } \text { erest }}{E B I T}$

2. Interest coverage $\frac{E B I T}{\cos t s_{-} \text {int erest }}$

3. Leverage $\frac{\text { assets }}{\text { equity_capital }}=1+\frac{d e b t}{\text { equity_capital }}$

II) Ratio of liquidity measures company capacity to settle its short-term liabilities

1. Current ratio current_liabilities

2. Quick ratio $\frac{\text { cash }+ \text { marketable_securities + claims }}{\text { current_liabilities }}$

3. Cash ratio $\frac{\text { cash + marketable_securities }}{\text { current_liabilities }}$

RATIO OF INCOME STATEMENT AND RATIO OF INCOME STATEMENT/BALANCE SHEET

III) Ratios of activity measure how efficient a company is in using its assets

1. Turnover of total assets $\frac{\text { turnover }}{\text { average_total_assets }}$

2. Turnover of constant assets

$$
\frac{\text { turnover }}{\text { average_cons tant_assets }}
$$

3. Inventory turnover $\frac{\cos t s \_o f \_s o l d \_ \text {products }}{\text { average_inventory }}$

4. Average collection period $\frac{\text { average_claims }}{\text { annual_turnover }} * 365$ 
Maja ANDRIJASEVIC, Vesna PASIC. A Blueprint of Ratio Analysis as Information Basis of Corporation Financial Management

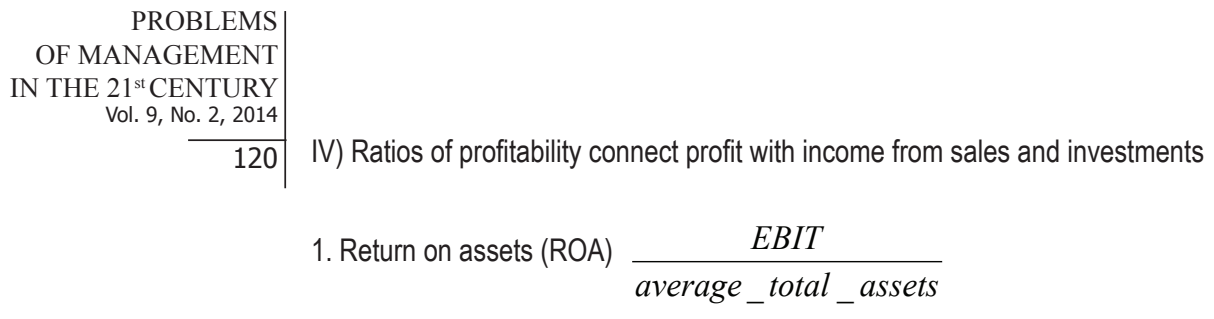

2. Return on equity capital (REC) $\frac{\text { net_profit }}{\text { average_equity_capital }}$

3. Return on turnover (profit mark) $\frac{\text { EBIT }}{\text { turnover }}$

Source: Zvi B., Alex K., Alan J.M., (2009) Basics of Investments, Data Status, Belgrade, page 443 and James C.V.H., John M. W. (2007) Basics of Financial Management, Data Status, Belgrade, page 135.

It also should be noted that ratios are not worldly standardized, meaning that there is no universal model for optimal business strategy. (Aleksandar M., 2008, pp. 68-74) In that context, ratios can be divided in the following way:

- $\quad$ Financial balance - including a set of ratio numbers pointing to the short-term financial balance - liquidity and long-term financial balance - solvency,

- $\quad$ Structures - referring to ratios of global and 'scattered' structure of property and capital - in balance sheet and income and expenditures - in income statement,

- $\quad$ Rational management - referring to turnover coefficients and are in function of efficiency of management over certain forms of property,

- $\quad$ Efficiency - including assessment of profitability, economy, productivity and market value - including ratio numbers pointing to the company earning capacity and its efficiency in costs management and provide information on effects of investments of shareholders into a company.

Ratio numbers are also used with the models for predicting bankruptcy known as Altman - Z score test, developed in 1968 by Edward Altman to assess potential bankruptcy of a company (Altman, 2005). The model is also used by banks when making decision on approval of loans to potential clients. The decision is made on the basis of previously defined limiting value representing the standard assessing the condition in which the company finds itself (Altman, 2005). The bank approves of a loan only if Z-score of a company is above the defined limiting value and vice versa. Limiting values, this model is based on, are as follows:

- $\quad \mathrm{Z}$ is below 1,81 - bankruptcy zone

- $\mathrm{Z}$ is above 1,81 , but below 2,99 - gray zone

- $\quad \mathrm{Z}$ is above $2,99-$ safe zone.

Since the original model was established for joint-stock companies whose capital has market value, it was necessary to adjust the model to the operational conditions of private companies. The revised model has new $\mathrm{X}_{4}$ variable and new limited values as follows: lower $\mathrm{Z}$ $=1,23$ and upper $\mathrm{Z}=2,90$.

Altman's Z-score test has certain disadvantages in the sense that it cannot abstract accounting errors and it also neglects cash-flow indicators because one cannot ignore the fact that the flows of profitability and cash-flows often do not match. This test should be used as an addendum to financial analysis and it should be interpreted very cautiously. (Altman, 2005) 


\section{Advantages and Disadvantages of Ratio Analysis}

According to the author, when using information obtained by the analysis of financial situation one should take into account that this analysis basically is rough approximation of financial condition of a company and being such it does not completely meet the needs of internal users for many reasons:

- $\quad$ balance sheet is a statistical report and therefore the calculated indicators point to the state of liquidity and solvency on a particular day wherein one ignores the fact that the state of assets and the state of liabilities above all, short-term ones, are very dynamic categories that are subject to changes on a daily basis;

- $\quad$ set of rules (horizontal and vertical financing rules) are quite rigid ones and are based on the principle of protection of creditors. They do not take into account the nature of the activity a company operates within, crediting capacity, degree of risk preferences, cost of cash keeping and the fact that liquidity is basically opposed to the request of profitability;

- $\quad$ claims are taken as a priori liquidity position without access to empirical assessment of the degree of their chargeability and without the possibility of monitoring timeliness of collection. One also has neither access into creditworthiness of customers nor can he calculate the differential cost of investment in receivables according to which one might formulate the crediting policy;

- $\quad$ liabilities are summarized without timeliness of collection and therefore their dynamics cannot be either compared with the dynamics of claims collection or can one make the adequate judgment on validity of procurement policies payments to suppliers by calculating the rate of cost of the missed cash-discount;

- model of historical value is not able to cope with the effects of changes in prices, particularly non-monetary assets;

- $\quad$ it seems that that too summed up assets positions do not provide an opportunity to assess how fast it can be mobilized through amortization which is the precondition of the policy of one's own capital. On the other hand, to determine the height of one's own capital, one has to take into account the effect of leverage that provides higher rate of return on one's own funds;

- for analysis of coefficient of the turnover of suppliers, financial reports, apart from not containing the data on amount of annual procurements on credit also do not contain information on the position of goods and services procured at the market, or on the behaviour of competition which is of importance for assessment of adequacy to select a supplier and to plan the strategy of payables towards suppliers. Deadlines for maturity of liabilities and terms of payment (advance, prompt or deferred) also exceed information capacity of financial reports, although such information is important for assessment of creditworthiness of a company and it also enables calculation of the rate of cost of the missed cash-discount aimed at formulating the procurement policy;

- $\quad$ analogous to the previous, with the analysis of customer turnover ratio, financial reports, apart from not providing information on the amounts of the executed sales on credit, they also do not provide any insight into the deadlines of debt collection, credit standards, i.e. customers crediting policy and creditworthiness of customers nor the evaluation criteria of such a policy. Absence of information on credit policy also disables calculation of differential gain of the sale and differential cost of investments into claims of customers as evaluation criteria of the set credit standards;

- $\quad$ regarding the supplies, financial reports do not provide information on the applied methods of calculation of supplies reduction although they have different implications on the presented value of the supplies in balance sheet and on the calculated 
PROBLEMS

OF MANAGEMENT

IN THE $21^{\text {st }}$ CENTURY Vol. 9, No. 2, 2014

122

result, more precisely, costs of material in income statement which is certainly significant for their evaluation.

According to the author, when using information obtained by performance analysis, i.e. making decisions based on them, one should take into account the following:

- incomes and expenses in the income statement, if they correspond but are not identical with the incomes and cash emission. Each presented expense does not automatically mean outflow of the funds from a company (e.g. costs of amortization) nor every presented income means their inflow (e.g. increase in the value of supplies);

- $\quad$ related to this, certain types of costs presented in income statement, above all, costs of amortization and material, should be accepted with the certain amount of reserve since the balance does not contain data on the manner of reduction of value of fixed assets through amortization or the accepted methods of a decrease in value of supplies;

- $\quad$ balance sheet using the method of total costs is not an adequate instrument of performance analysis of smaller organizational units in a company or rating profitability per, for instance, product lines or market segments;

- $\quad$ with the performance analysis it is very important to monitor trends indicating the necessity of holding information from the balance of several successive operating periods;

- for evaluation and interpretation of the value of indicators comparative analysis is also very important, requiring additional information from the environment, particularly information on competition.

So, as with the analysis of the balance sheet, it can be said that the analysis of the income statement is a valuable source of data required to meet with a score of business operations in a given period of time, but for the needs of making particular decisions this analysis should be amended and adjusted to the specific needs of internal users.

\section{Final Considerations}

Although balance sheet and income statement from the financial point of view are exceptionally important, since they represent the necessary source of information for financial analysis and making financial, they are not sufficient for evaluation of all relevant aspects of financial activity of a company. In addition, ratio analysis as a technique has its limitations that are in practice often ignored. Some of these limitations are possible to at least reduce in a relatively simple manner, while others require serious engagement of wider community.

What can be done to raise the level of quality of information obtained by ratio analysis, is the following:

- $\quad$ an analyst, in calculation of ratio indicators, should take all values from balance sheet at their average value to reduce the static of the report.

- $\quad$ one should, to the maximum extent, use the data from additional financial reports (remarks, annexes, etc.) on whose information capacity it is necessary to engage professional associations of accountants.

- $\quad$ professional associations could also initiate publishing of regular annual publications with the basic ratio indicators of specific industries so that the analysts would have real basis for comparison of results and possibility to monitor trends.

- making conclusions and evaluation of ratio indicators based on their comparison with the rules of financing is more than unrealistic and therefore nobody should insist upon them. 
- $\quad$ an analyst certainly should be aware of the fact that neither method nor technique alone is perfect, so in that sense, ratio analysis should be used as an element of mix of various methods of evaluation of financial state and efficiency of a company.

The last but not the least, we should accept the fact that by insisting on financial analysis other aspects of the analyses are, in practice frequently marginalized, thus neglecting the fact that actually they themselves in the most direct manner point to the causes of potential disorders in business activities of a company. In addition, analysis of other tangible and intangible resources is the starting point in planning financial effects of their utilization that are examined through financial analysis later on.

\section{References}

Aleksandar, M., (2008). Osnovni pojmovi i pokazatelji finansijske analize kao neizbežni segmenti upravljanja u cilju rasta i razvoja preduzeća [Basic concepts and indicators of financial analysis as inevitable management segment aimed at growth and development of a company]. Ekonomika, $1-2,68-74$.

Altman, E. I. (2005). An emerging market credit scoring system for corporate bonds. Emerging Markets Review, 6, 311-323.

James, C. V. H., \& John, M. W. (2007). Basics of financial management. Belgrade, Serbia, p. 133.

Knezevic, S., Barjaktarovic, S., Rakocevic, \& Djuric, D. (2001). Primena i ograničenja racio analize finansijskih izveštaja u poslovnom odlučivanju [Application and limitations of ratio analysis of financial statements in business decision-making]. Management for Theory and Practice, 61, 2531.

Malinić, D., Milićević, V., \& Stevanović N. (2012). Upravljačko računovodstvo [Management accounting]. Beograd.

Stavrić, B. (2010). Ekonomika preduzeća - teorija poslovne ekonomije [Economics of the company theory of business economics]. Beograd: KIZ Centar.

Zvi, B., Alex, K.., \& Alan, J. M. (2009). Basics of investments. Belgrade, Serbia: Data Status, p. 437.

Advised by Jorge Lima de Magalhães, Oswaldo Cruz Foundation/FIOCRUZ, Brazil

Received: May 09, 2014

Accepted: July 16, 2014

PROBLEMS

OF MANAGEMENT

IN THE $21^{\text {st }}$ CENTURY

Vol. 9, No. 2, 2014 